\title{
Households and entrepreneurship in England and Wales, 1851-1911
}

The relationship between the household and entrepreneurship has long been attested by historians, economists and scholars of business. This article considers how the availability of household resources affected the likelihood of individuals running a business and the kind of business they ran in Victorian and Edwardian England and Wales. Most historiography on the household and the firm in England and Wales and elsewhere has focused on the question of family firms, succession, their supposed inefficiency and their impact on national economic performance (e.g. Chandler, 1990; Church, 1993; Ehmer, 2001; Nagata, 2017; Nenadic, 1993; Nicholas, 1999; Rose, 1993; Scranton, 1993). The questions addressed here are rather different. Instead of examining a handful of case studies to consider how familial concerns influenced business decisions and whether they were less rational as argued by some scholars, or whether succession issues prevented long-term success as argued by others, this article uses population-level data to investigate the demographic and household characteristics of entrepreneurs, and to examine three common forms of business organisation based on the household: co-resident family businesses, co-resident partnerships, and coentrepreneurial households.

The first business form is households in which an employer employed relatives who were present in the same household. The second from is households in which two individuals, related to each other or not, were entrepreneurs engaged in the same trade. The third form is households in which entrepreneurs lived with each other but were operating in different trades. In each case the resources of the household were used to support and enable entrepreneurial activity. This not only helps explain the incidence of entrepreneurship, it also sheds light on the contribution to business provided by a range of family relationships (of wives, husbands, children and other relatives) as well as or household members that are often 
hidden from view in many studies of entrepreneurship that focus on the business proprietor only.

This analysis provides a new window onto the social history of the household economy. This topic has been fruitfully examined by historians investigating the gendered division of labour, but comment has tended to be restricted to studies of waged workers (Burnette, 2008; Hofmeester and Meerkerk, 2017). However, the household was of vital importance to many businesses in the nineteenth and early twentieth centuries. Any individual starting a business, as a bare minimum, needed access to capital and labour. While banks did lend money to small businesses, the majority of firms were reliant on family connections for capital (Capie and Collins, 1996). This sometimes came in the form of loans but was often inheritance or money given to individuals at the time of their marriage; family capital was especially important given the relatively small capital outlays required in many firms (Cottrell, 1980, pp. 236-44; Crossick, 2000, p. 70; Davidoff, 2012, pp. 57-8; Owens, 2001). In such cases the formation of a new household and a new business may well have been simultaneous events, with the business, marriage and household formation all shaping each other. Labour was easier to obtain in many places given the mobile English and Welsh population and relatively unconstrained labour market. However, in some remote areas familial labour may have been the only, or the easiest, option for a business proprietor. As we will see below this was especially important in agricultural areas in the north of England and in Wales. Even where non-familial labour was easily available there were some benefits to its use as it changed the worker-employer relationship to a family one, which could bring its own difficulties, but removed many associated with the labour market and, if a child was being employed, meant that the proprietor embodied the cultural, political and economic power of both an employer and a parent. Doing so could reduce labour costs and, could also result in exploitation of family members as they undertook work without receiving the kind 
of renumeration they could have received for such work in the labour market (Colli, 2003, p. 4). However, this may have been the only way to maintain a viable business in its local circumstances. Beyond the basics of capital and labour, family and household members could provide training, contact networks, specialized knowledge and other opportunities and advantages to a business which otherwise would have had to be purchased in the market, if available. In doing this, the paper also contributes to the extensive literature on how demography, family formation and structure affected economic change (Medick, 1976; Smith, 1981).

This article examines how business proprietors in Victorian and Edwardian England and Wales used their household resources in their businesses. It does this at a national scale using big data in a way not before done for historical data and shows how different forms of household business organisation varied by time, location and sector, and how they interacted with the demographic characteristics of the entrepreneurs themselves. The data used comes from the British Business Census of Entrepreneurs (BBCE). This database was derived from the electronic versions of the censuses of England, Wales and Scotland created by the I-CeM project (Schürer and Higgs., 2014). The paper focuses on England and Wales, using every identifiable entrepreneur in the population census for the census years 1851-1911.

\section{The Census, Families, Households and Entrepreneurship}

A strength of the censuses is that they allow examination of the households of known entrepreneurs and identification of a number of different kinds of family- and householdbased entrepreneurship. The census for England and Wales was carried out every ten yeas from 1851 and this article uses data from the 1851 to 1911 censuses. The English and Welsh census was carried out by means of schedules that were distributed to each household to be 
filled out by the head of that household. They were to report information on every individual present in that household on the night of the census. A single house might contain multiple households, and a single household might not correspond to a single family as the head of the household had to report all individuals present in that household on the night of the census including visitors, servants, boarders, apprentices, co-resident workers and others. The definition of the household and of who counted as a head of household changed from census to census, mainly to deal with the complex issue of lodgers (Higgs, 2005, pp. 72-4). For this reason, no lodgers are included in the analysis in this paper. With this exception the census includes information on the relationship of each individual to the head of the household that allows family units to be reconstructed.

The census also asked questions about the occupation of each individual and about their employment status. In the 1891-1911 censuses this question asked people to report whether they were workers, employers or own account. ${ }^{1}$ In the 1851-1881 censuses employers were asked to return themselves as such and to state how many people they employed. Farmers were asked to do likewise and to also report the acreage they farmed. Finally, masters were asked to identify themselves as well, regardless of whether they employed anyone. The BBCE has extracted these data for the first time from the electronic version of the censuses provided by I-CeM and corrected them for non-response issues to create a consistently defined, whole population database of employers and own-account business proprietors between 1851 and 1911 (Bennett et al., 2019b). These are the individuals referred to here as entrepreneurs. For the 1891-1911 censuses these categories derive from the direct returns given by individuals answering a question specifically asking about employment status. However, for 1851-1881 individuals are identified in BBCE from their

\footnotetext{
${ }^{1}$ Own account refers to individuals who were self-employed sole proprietors.
} 
occupation statements. ${ }^{2}$ If they reported workforces they have been assigned employer status and if returned themselves as masters or farmers but gave no workforce have been assigned own-account status. These data are used directly here. However, not every employer or ownaccount proprietor responded fully which limits the completeness of the 1851-81 analysis. The BBCE provides supplemented responses to identify non-respondents. However, the supplements are not used here except to identify potential partners or co-entrepreneurs as defined below. ${ }^{3}$

As the census contains no information on ownership it is not possible to use the normal kinds of legal definitions for family firms (Colli and Rose, 2007). Much historical analysis of family firms, especially that concerned with their deleterious or other effects on British economic performance, has usually had little interest in the makeup of the households and families of the entrepreneurs they analysed. However, it is clear from other work on the economic history of Victorian and Edwardian Britain that the household was a vital unit of economic analysis, even if the position and role of different members of the household changed, especially with regards to gender relations, and particularly but not exclusively for smaller firms. Furthermore, the household was more than just the immediate family, it took in the resources of more distant relations, lodgers and boarders (Davidoff and Hall, 1997; de Vries, 2008, pp. 186-237; Owens, 2002). Additionally, the household is necessarily strongly affected by demography. An individual or couple may start a firm intending it to be a crossgenerational enterprise driven by a particular ethos but their ability to fulfil this intention is determined by demographic behaviour, how many children they have and how many survive to adulthood, even before the issues of 'talent' and success enter the equation. Consequently,

\footnotetext{
${ }^{2}$ Note that the census information for 1871 is not currently included in I-CeM for England and Wales.

${ }^{3}$ BCCE supplementation is based on a logit model to which assigns employment status based on demographic characteristics, occupation and location. This is an approximation. Most farmers, but around 40 per cent of nonfarm employers, returned their workforces, the rest had to be supplemented. This process helps to identify other proprietors in the responses; it is explained in detail elsewhere (Bennett et al., 2019b).
} 
it is clear that any discussion of the role of the family in businesses must take in a wider range of issues than those normally addressed by the literature.

Three kinds of household firms can be identified from the census. First, firms in which a business proprietor employed relatives in his or her business. Thus, a father might employ his children in a business, such as Fred MacKinney, an optician and watchmaker, who in 1901 was likely employing his daughters Elizabeth and Ursula in his firm (Fred Mackinney, 1901). Although the census does not explicitly state that this was the case, it is highly probable that in most instances of this kind the two daughters were in the father's employment as they were recorded as workers in the same occupation as their father who was recorded as an employer. We can identify every instance in which an employer was living in the same household as family members working in the same industry. This is a particular kind of family business, one run for the economic support and benefit of the family, and also one which used family labour. There will also have been entrepreneurs who employed family members but who did not live with their familial workers, but unfortunately these cannot be identified en masse from the census records because households are identified, but not interrelations between households.

The second kind of household firms identifiable in the census are partnerships between people living in the same household, such as Mary and Ann Dodman who were sisters and partners running a school in Clapham in 1891 (Mary Dodman, 1891). Any coresident entrepreneurs in the same occupation in the census can be extracted and examined. The census only rarely records explicit 'partners', but the Dodmans are typical of many cases which will normally have been 'implicit partnerships'. This approach does not identify all partners in the census, but a substantial sample can be obtained.

The final kind of household-based entrepreneurship that can be identified in the census are households containing more than one entrepreneur, each running different 
businesses. This kind of familial entrepreneurship has been examined in eighteenth-century Britain, but otherwise is little examined in existing literature (Erickson, 2008). However, it can be considered as a kind of portfolio entrepreneurship with a family running multiple businesses in order either to diversify or expand their entrepreneurial activities, or out of necessity. This could be either a business growth strategy, or as a means of survival because any one activity was insufficient for family needs. Within each of these three kinds of household firms some involved just family members, some only non-family members such as boarders and lodgers, and others a mixture.

These three kinds of household firms do not exhaust all forms of family business in this period. Many family firms will have involved individuals from the same family who lived in different households and those are generally invisible to us given the fact that the census records little about the relationships between households as opposed to with households. ${ }^{4}$ The approach used to co-resident family firms and the implicit partners assumes that workers or entrepreneurs in the same occupation in the same household were involved in the same firm. There will have been cases where this was not true but normally they will be in the same firm. First, in many cases the workers explicitly stated that they were working for the entrepreneur in the household. For example, in 1901 James Sambridge had the occupation 'Nurseryman Son Working for Father', and he was resident with his father, also James Sambridge, an employer whose occupation as 'Nurseryman in Flowers' (Sambridge, 1901). Secondly, leaving home and creating a new household in this period was commonly associated with a degree of economic independence, whether setting up their own business or entering waged employment (Wall, 1987; Pooley and Turnbull, 1997). This makes it more likely that individuals resident with an entrepreneur and stating that they worked in the same

\footnotetext{
${ }^{4}$ One exception is explicitly identified partners, namely those individuals who reported themselves as partners in such a way as to allow their partners who lived in different households to be identified. We have examined these individuals elsewhere (Bennett, 2016).
} 
occupation were involved in the same business, since if an individual was running a different business in the same trade it is likely they would have formed a separate household. Similar assumptions apply to waged workers operating in the same trade as an entrepreneur with whom they were living. Although this will not have been true in all cases, but the balance of probabilities is that, given the usual behaviour regarding leaving home in this period, individuals in the same household engaged in the same occupation will have been doing so in the same firm. The consequence of this is that the figures for household firms given below are likely upper limits for the numbers of such firms that can be identified.

It is important to note that because of the other type of family firm that existed, and the limitations of the census for fully recording each the three types on which we focus, it is not possible to state what proportion of all family firms each constituted. Hence, the following analysis focuses primarily on the characteristics of each firm type and withholds from concluding on their relative frequency. However, the absolute numbers quoted below may indicate that co-resident family businesses were probably the most frequent, with implicit partnerships and co-entrepreneurial households perhaps being of similar and lower frequency.

\section{Entrepreneurial households}

Before examining the kinds of household entrepreneurship present in 1851-1911, it is necessary to understand the general structure of entrepreneurial households in those years. Entrepreneurs were far more likely to be heads of household than workers, who were, in turn, more likely to be members of a Conjugal Family Unit (CFU) (spouses and children), other family members (grandchildren, nieces and nephews, cousins and others), servants (unsurprisingly), or lodgers and boarders. This reflects the fact that entrepreneurs tended to be older than workers and that starting a business and heading a household were activities 
undertaken at a similar point in the life cycle, mostly after from about age 35 (Bennett et al., 2019a, pp. 164-68). In every census year heads and CFU members of heads accounted for 90 per cent or more of all entrepreneurs, and this was remarkably stable despite the level of structural change occurring in business organisation and the economy over the period (Bennett et al., 2019a, p. 176).

Table 1 gives the mean houseful size of households headed by entrepreneurs with those headed by workers. ${ }^{5}$ This shows that entrepreneurs tended to have slightly larger households, but that the difference was small. However, when the kinds of individuals constituting those households is examined there are more important differences. Using 1901 as an example, households headed by an entrepreneur contained, on average, $2.7 \mathrm{CFU}$ members, 0.3 other family members, 0.4 servants, and 0.2 inmates (lodgers, boarders etc.), while households headed by workers were generally larger but with less servants, containing 3.1 CFU members, 0.2 other family members, 0.07 servants and 0.24 inmates. This pattern is found in all years. Thus, the higher number of servants was the main cause of entrepreneurs having slightly larger mean houseful sizes overall, something which reflected either higher incomes on average for entrepreneurs compared to workers, or the utility of servants for businesses where they could free family members from domestic duties to allow them to be active in the firm and could also work in the firm themselves (Higgs, 1983; Outram, 2017). In contrast, entrepreneurs had lower CFU size. This is partly explained by them being older, and hence in a life cycle stage were more of their children may have left home, but also because workers had higher fertility than entrepreneurs ((Bennett et al., 2019a, pp. 174-6).

\section{Table 1 near here}

Entrepreneurs also had somewhat different household structures compared to workers. Table 2 gives the proportion of entrepreneur- and worker-headed households with different

\footnotetext{
${ }^{5}$ Houseful includes the household head, relatives, servants and residential inmates (boarders, lodgers etc.)
} 
household types in 1901, although the pattern holds for all years (Laslett, 1972, pp. 28-32).

This shows that entrepreneurs were more likely to head extended households than workers; extended households contain a CFU and relatives other than offspring. This pattern was true not just for large-scale industrialists or wealthy merchants but for entrepreneurs of all statuses, firm size, and incomes. Thus, in 189123 per cent of own-account-headed households in nail manufacture were extended compared to 14 per cent of worker-headed households in that relatively precarious industry. ${ }^{6}$ Such data supports the argument that aunts, uncles, brothers, sisters and other extended family members were particularly important for entrepreneurial families. The reasons for this varied with each family's circumstances (Davidoff, 2012, pp. 78-195). For some, these extended family members provided valuable capital, labour and contacts; for others employment in a family's business was a means of maintaining family members who struggled to find waged labour for various reasons: cultural impediments, lack of skill, old or young age. Indeed, the family's business was one route to respectably utilise the increasing number of unmarried men and women in Victorian England and Wales (Anderson, 1984, pp. 378-9, 1990, pp. 67-8; Garrett et al., 2001, pp. 214-16).

\section{Table 2 near here}

Entrepreneurial households, therefore, were somewhat different from those including only workers. The two categories, entrepreneur and worker, contain a wide variety of individuals; entrepreneurs ranged from transnational merchants worth millions to singleperson hawking businesses struggling to survive, while workers covered both itinerant labourers and the highest ranks of the civil service. Yet, despite the heterogeneity within these categories, differences remained: entrepreneurs were more likely to have servants within their households, and more likely to be living with people who were not their spouse

\footnotetext{
${ }^{6}$ Own account is the census status that describes an entrepreneur as a sole proprietor employing no-one else (except perhaps undeclared family members).
} 
or their children. In both cases the nature of entrepreneurial, as opposed to waged, economic activity both drove such differences and was driven by them. Entrepreneurs were likely to have slightly larger households than workers and to live with other adults; this added burden may have spurred individuals to start a business with an eye on the potentially greater income available, but may have attracted additional people to join to household as it offered work, and the additional resources provided by other household members would have been valuable to any business proprietor. Likewise, servants may be evidence of additional income provided by entrepreneurial activity but were also a resource that enabled such activity, either through direct work in the firm or by freeing up household members' time by performing domestic duties.

\section{Co-resident family businesses}

Table 3 shows the number of co-resident family businesses: those households in which an entrepreneur employed family members. Some entrepreneurs also employed non-family household members such as boarders and lodgers, but these have only been included if they also employed at least one family member as well. Those only employing non-family members have been excluded. For the 1891-1911 censuses the entire population of employers can be examined to find these co-resident family businesses because the census question recorded their employment status as worker, employer or own-account proprietor. However, for the earlier available censuses $(1851,1861$ and 1881), as noted earlier, the employers reporting their workforce can be identified reliably. These have been used here with no supplemented data. This means that the data on early (1851-81) and later (1891-1911) censuses used in the following tables is not strictly comparable and the figures for 1851-1881 are underestimates of the total of co-resident family businesses.

\section{Table 3 near here}


The break in the census, as well as variation in census enumerator practice, mean that it is hard to judge the trend in these data. ${ }^{7}$ It seems that co-resident family businesses were becoming less common across the period 1851-81. The pattern in the later period is more complex; 1891 may have been a dip and 1901 a partial return to normal levels which the fell by 1911 .

These kinds of business were more likely to be headed by a woman than businesses in general, although still only 10-14\% were female-headed (Bennett et al., 2019a, p. 182). This gendered aspect of co-resident family firms interacted with the other familial relationships within each household. It was more common for female employers to be involved in a business with their daughter than male employers; for example, in 191116 per cent of female employers in these businesses were working with their daughter compared to just six per cent of men. It was also more common for women to be working with their sisters than men; in 1911 the figures for female employers were nine per cent compared to two per cent for male employers.

Furthermore, while men were most important numerically to co-resident businesses where the relationship was either with male relatives or a mixture of male and female relatives, female employers were more common in daughter- and sister-only businesses, as shown in Table 4. Some of this pattern is explained by the gendered restrictions on female activity in some areas of economic activity, such as heavy manufacturing. However, it is clear that co-resident family businesses were an important form of business organisation for female entrepreneurship in this period. Furthermore, the decline in the overall number of this kind of firm between 1901 and 1911 contributed to the general drop in female entrepreneurial

\footnotetext{
${ }^{7}$ Some enumerators were more assiduous in recording household members' occupations; for example, in 1901, over half of the male residents of the parish of Kenton in Devon who were aged between 15 and 65 (people we would expect to mostly be occupied) and who were not heads of households, had no occupation. In contrast, all but 35 of the 7,267 men with the same characteristics in the parish of Portland (part of Weymouth) had occupations. This indicates that the geographical variation in the presence of co-resident family businesses was related, in part, to enumerator variation.
} 
activity observed in this period and represents one of the ways in which women were squeezed out of the business proprietor population at the turn of the nineteenth century. It should also be noted that this method of identifying a particular kind of family firm simply makes obvious what is often hidden in the other firms identifiable in the census, namely the contribution of wives, daughters and other female household members to the entrepreneurial activity of men.

Finally, this gendered aspect of the co-resident family firm also interacts with marital status to reveal an interesting picture. The majority of sister-only businesses were headed by a single woman; in 191182 per cent of women who were running a business employing at least one sister were single. In business in which daughters only were employed their mother, the female employer was likely to be a widow, but a substantial minority were run by married women. Again taking 1911 as the example, 64 per cent of women running these businesses were widowed, but 23 per cent reported that they were married. ${ }^{8}$ These sister-sister and mother-daughter businesses were mostly grocers, dressmakers and laundresses, areas in which female market entry was easier, and hence female entrepreneurship was common. However, they were less frequent in one important sector, farming: in 19016.8 per cent of mother-daughter and 9.8 per cent of sister-sister businesses were running farms as opposed to 21.5 per cent of all female employers.

\section{Table 4 near here}

There was also important geographical variation in co-resident family businesses. These businesses were most prominent in more remote areas such as west and north Wales, rural northern England and Devon, especially upland areas most associated with farming where the head's business was often a key source of employment for family members unless people migrated. This is also clear in the breakdown by urban area; in 190146 per cent of

\footnotetext{
810 per cent of these women were married with their spouse absent, which was an ambiguous marital condition.
} 
these businesses were in urban Registration Sub Districts (RSDs), 17 per cent in RSDs transitional between urban and rural, and 37 per cent in rural RSDs. ${ }^{9}$ In comparison, in 1901 64 per cent of all employers were in urban RSDs, 15 in transitional RSDs and just 21 per cent in rural RSDs. These co-resident family firms offered a useful model for rural entrepreneurship where the supply of labour was scarcer.

The sector distribution of these co-resident family businesses showed marked concentration in farming. They were over $70 \%$ of all such businesses in $1851-81$, and although the comparisons over time are constrained, they were 50-60 per cent of all coresident family businesses over 1891-1911. Beyond agriculture, co-resident family businesses were more suited to sectors that were characterized by small-scale economic activity in which home-based production and retail was common. Thus, they were more common in makerdealing (especially tailors, blacksmiths, shoemakers, dressmakers and chemists) that made up 5-10 per cent of all such firms, food sales (particularly grocers, butchers, bakers and cowkeepers) where they made up 5-13 per cent, and manufactures where they made up 4-8 per cent. They were uncommon in transport, mining, refreshments, finance or the professions which all had less than one per cent co-resident family businesses. The largest proportions were in many maker-dealer, retail and food sales trades such as (for 1901) 43 per cent of employer blacksmiths, 30 per cent of dressmakers, 32 per cent of grocers and 44 per cent of bakers who employed a family member who was living with them. The sizeable numbers of co-resident family firms in construction and manufacturing were generally involved in smallscale manufacturing or, if in the construction sector, they were in the areas of that sector in which small businesses were the norm, especially carpentry, plumbing and house painting. These firms were not much involved in heavy manufacturing or building contracting. The trend over time in sector concentration of co-resident firms is difficult to discern, given the

\footnotetext{
${ }^{9}$ For this urban classification see (Smith and Bennett, 2017).
} 
changes in the census format. However, among the major sectors, it does appear that there was a decline of them in farming and maker-dealing, and probably a rise in manufactures, retail and food sales. There were perhaps some changes to this trend after 1901, with a decline in co-resident firms in retail and food sales. This may mark changes in line with the general shifts in the economy in the late nineteenth-century as firm sizes were generally increasing and industry was becoming concentrated, with retail and food sales seeing rapid expansion of branches of national and regional chains (Hannah 1983; Jeffreys 1954).

Overall co-resident family businesses were characteristic of trades with small-scale entrepreneurs, especially farms, maker-dealers and food sales. They were more likely to be found in rural areas and were likely to be in sectors where there were few large firms; the exception was farming, but even there these businesses tended to be smaller than other businesses: in 1881 the mean workforce size in co-resident family farms was 5.2 compared to 9.5 for other farmers (Bennett et al., 2019a, pp. 185).

\section{Household partnerships}

Partnerships were a common form of business structure in this period. Table 5 gives the number of households in each year with two or more entrepreneurs in the same occupation, which we interpret as implicit household partnerships. Explicit partnerships, those stating they were a 'partner' or working with someone else in the household were recorded on too small a scale in the census to be included here, but are the subject of closer analysis by the authors elsewhere. ${ }^{10}$ For implicit partnerships, family household partnerships involved family members only; non-family partnerships include at least one non-family household member.

\footnotetext{
10 The census questions did not explicitly ask for information on 'partnership' and hence what is available occurs only as a chance that it was recorded by household heads. Analysis of those that were explicit is given in Bennett, 2016).
} 
In this type of household firm businesses, as table 5 shows, the majority of implicit partnerships did not involve non-family household members.

\section{Table 5 near here}

Considering the previously mentioned difficulties of comparing the early and later censuses, the proportion of entrepreneurial households (those households with at least one entrepreneur present) which contained an implicit partnership was relatively small and stable throughout 1861-81 and 1891-1911. The proportion was slightly higher in 1851; as with co-resident family firms this was partly due to the larger number of farming entrepreneurs in that year compared to other years, with maker-dealers the second, and a more major proportion, than for co-resident family businesses. Table 6 gives the share of these implicit partnerships in 13 sectors and shows that farming formed a similar proportion of implicit partnerships in the 1851-81 censuses, but there were numerically more farming households in 1851 . For the maker-dealer sector, in 1851 these partnerships were more common than in 1861 or 1881 , and the number of households with one or more maker-dealer in them was greater, hence the higher proportion of partnerships overall.

\section{Table 6 near here}

Although the break between 1881 and 1891 makes long-term comparison difficult, it is striking that while the proportions change, the pattern was similar in all years. Household partnerships were common in farming, manufacturing, maker-dealing, and food sales in all years, and in personal services from 1881 onwards. They were also of increasing importance in refreshments. Retail jumped dramatically after 1881 , a change caused by the different modes of identifying entrepreneurs in the earlier and later census questions, but the relative stability of the proportions for both periods suggests that there was little real change occurring. In the case of farming, retail, maker-dealing and food sales, these were sectors characterized by smaller firms and a low level of incorporation, and it is likely that 
partnership was, therefore, a flexible kind of business organisation which allowed resources to be pooled and risk managed without the costs incurred through incorporation (Hannah, 2014; Payne, 1988). In manufacturing, it is probable that the slight drop over this period was driven by some partnerships becoming companies; however, it is notable that in manufacturing these implicit partnerships were more common in the kinds of manufacturing that had low levels of incorporation. For example, in 1901 the five most common manufacturing occupations with household partnerships were cabinet making, printing, lace manufacture, upholstery and hosiery manufacturing, which were sectors that were slow to incorporate. The increase in personal service partnership between 1861 and 1881 reflects the changing composition of the extracted entrepreneurs; in 1861 just 0.6 per cent of extracted entrepreneurs were in personal services, in 18814.5 per cent were. Partly this was a real change, as personal services grew as a sector, but it was also partly that reporting of personal service entrepreneurs in the census increased. Implicit partnership was, therefore, found in most sectors and was a useful alternative to incorporation and sole proprietorship.

Table 7 shows the gender breakdown of these implicit partnerships. It is clear from the table that the use of data in the earlier censuses without supplementing for non-responses means that we are missing most female-only partnerships. However, it is also clear that implicit partnerships were fairly evenly distributed across all gender combinations and that this form of business organisation was as available to women as it was to men. There were occupational differences between the differently gendered partnerships. Female-only partnerships were particularly concentrated in maker-dealing (49.1 per cent of all such partnerships in 1901, mostly dressmakers) and personal services (22.6 per cent in 1901, mainly laundresses and teachers), thus mirroring the distribution of female entrepreneurship more generally (van Lieshout et al., 2019, p. 453). Male-only partnerships were more widely distributed among farming (22.1 per cent in 1901), manufacturing (12.5 per cent), retail 
(14.51 per cent) and food sales (13.2 per cent). Female-male partnerships were different again, maker-dealing was important (17.12 per cent in 1901, in dressmaking and tailoring mainly), retail (20.8 per cent, hawkers and drapers were most common), personal services (15 per cent, laundry work was the most frequent occupation) and food sales (17.2 per cent, grocers and bakers mainly). The concentration of female partnerships and the lack of femalemale or female-only partnerships in manufacturing or construction suggests that while partnerships were open to women, they did not allow women to access sectors usually dominated by men. The slight decline in female-only and female-male partnerships between 1901 and 1911 was driven by the drop in the number of female entrepreneurs. This drop was caused by the increased concentration of clothes production, which saw the number of female entrepreneurial dressmakers fall substantially in the first decade of the twentieth century as larger firms developed (Gamber, 1997, pp. 158-228). In that sense they reflected the general relationship between gender and entrepreneurship in nineteenth-century England and Wales.

\section{Table 7 near here}

Figure 1 shows the distribution of these implicit partnerships as a percentage of all entrepreneurial households in each RSD for 1901, first for non-farm entrepreneurs and then for farmers. In contrast to the clear concentration of co-resident family businesses referred to above, non-farm partnerships were found throughout the country with only a slight tendency to be more concentrated in more remote areas. Farmer partnerships were more common in the arable areas of England, but even here the distribution was not as concentrated as for coresident family businesses. Hence, in general, whilst the distribution of partnerships mirrored that of entrepreneurs more generally; in 1901, 28.4 per cent of entrepreneurs lived in RSDs containing towns with populations above 10,000, and 30.1 of implicit partnerships were found in such locations, rural RSDs contained 47.2 per cent of entrepreneurs and 45.7 per 
cent of implicit partnerships and transition RSDs comprised 24.4 per cent of entrepreneurs and 24.2 per cent of implicit partnerships.

Thus, implicit partnerships were markedly different forms of household entrepreneurship compared to co-resident family businesses. Whilst family businesses were concentrated in marginal sectors and locations, implicit partnerships were found throughout England and Wales and in all sectors. Indeed, they mirrored closely the wider sectoral and geographical distribution of entrepreneurs. This suggests that, as Hannah and others have argued, partnerships were a common form of business organisation available to entrepreneurs in all sectors, of all sizes, and in all locations. How many of these household implicit partnerships were unreported explicit partnerships based on formal deeds and how many were family firms without any explicit legal basis is impossible to know. However, it is clear that operating in households containing more than one entrepreneur in the same occupation was common in this period and offered advantages in terms of shared expertise, resources and risk.

\section{Figure 1 near here}

\section{Co-entrepreneurship households}

The final form of entrepreneurial household considered here is households in which more than one entrepreneur resided, but where such individuals were running different firms. Table 8 shows the number of these households for each year. The majority of these households were comprised of family entrepreneurs only, with a minority involving non-family household members. A small proportion of this group were households where the main resident family were non-entrepreneurs, but their boarders, lodgers or visitors were business proprietors. As with implicit partnerships these co-entrepreneurial households were a fairly stable proportion of all entrepreneurial households across this period. 


\section{Table 8 near here}

Table 9 shows the sectors in which these co-entrepreneurs were involved. For clarity a single year is shown, 1901, and only the first and second sectors of the activities in the household are analysed, although, a few households contained more than two entrepreneurs working in more than two sectors. The sectors of activity are in the order that individuals appeared in the household census schedule, which will normally mean that the first is the head (column) and the other entrepreneur is shown by the rows. For all sectors maker-dealing was the most common occupation of the second listed entrepreneur, except for professional and business services where personal services were equal to maker-dealing as the most common second sector. These patterns held for all years. Furthermore, within the second occupations, maker-dealer dressmaking was extremely common. In each first-named sector dressmakers made up 59 to 81 per cent of the maker-dealer second entrepreneurial occupations. The next most common second occupation varied from sector to sector; in manufacturing, retail, personal services and food sales the next most common second occupation was in the same sector, manufacturing with manufacturing and so on; for all other sectors it varied. Food sales were common in farming and transport, which makes sense considering the complementary nature of those trades; in farming, a household member could sell the goods produced by the farmer, in transport they could sell goods carried by the primary entrepreneur. In other sectors the commonality was less obvious, but laundry work and teaching music were common second entrepreneur occupations. These, along with dressmaking, were trades which could be performed from home, and as such were ideal areas for households to expand into to obtain a second entrepreneurial income, especially if the household member running that business would otherwise struggle to access waged labour, such as married women. Laundry work also had among the lowest entry costs and skill levels required. 


\section{Table 9 near here}

The particular involvement of women can be illustrated by looking at the gender breakdown and at the relationships between the co-entrepreneurs in each household. Table 10 gives the gender breakdown of the entrepreneurs involved in these co-entrepreneurial households and table 11 shows the kind of relationships between the co-entrepreneurs in each census year. Table 10 reveals that women were frequently involved in these entrepreneurial households, something which was likely given the high proportion of maker-dealers and especially dressmakers and laundry involved, sectors in which female entrepreneurship was common. Table 11 shows that while most of these women were engaged in entrepreneurship alongside a male relative, 5-10 per cent were doing so with a female relative, in motherdaughter or sister-sister entrepreneurial households. The most common first-stated entrepreneur's occupation here was dressmakers, who were often living with female milliners or shirtmakers, but also with musicians, music teachers, laundresses, confectioners and teachers. Other common first-stated occupations for all-female co-entrepreneurial households were lodging-house keepers, laundresses, grocers, farmers, drapers, shirtmakers and confectioners, all of these were most likely to be living with a dressmaker.

\section{Table 10 near here}

Beyond this, father-children co-entrepreneurship was the most common combination, but the proportion of father-son and father-daughter co-entrepreneurial households were similar throughout the period. In father-daughter households, the daughter was usually engaged in dressmaking. For example, in 1851, in 77 per cent of the father-daughter coentrepreneurial households the daughter was running a dressmaking business. In contrast the sons in the father-son co-entrepreneurial households in 1851 were spread amongst a far wider range of occupations. The most common was carpentry, but this accounted for just 8 per cent of all father-son households, and the ten most common occupations only accounted for 45 per 
cent of all such households. ${ }^{11}$ Husband and wife co-entrepreneurial households were also common throughout this period, where again for wives dressmaking dominated. The high proportion of family-non-family relationships seen in 1851-81 compared to later years was caused by the higher proportion of non-family entrepreneurs who can be identified directly for their census responses as employers or masters as in 1851-81 compared to the total entrepreneurial population in 1891-1911, because the earlier data contains a higher proportion of farmers.

\section{Table 11 near here}

Finally, the geography of these co-entrepreneurial households is shown in Figure 2 for 1901. The distribution of co-entrepreneurial households was similar to that of implicit partnerships shown in Figure 1, suggesting, as also shown in the above tables, that this was a common household strategy, and it was widespread across the country throughout England and Wales. There is perhaps a slightly higher concentration in the counties ranging from Leicestershire to Hertfordshire, which might interact with hosiery and the straw plait industry, but this is a weak pattern. There is also a weak distinction of relatively low incidence of co-entrepreneurial households in the Welsh Marches, parts of South West England, and mid-Lancashire which may reflect interactions with dairy farming, but again this is a minor feature.

\section{Figure 2 near here}

In summary, the proportions of all types of co-entrepreneurial households were fairly stable across the period, save for those involving women where the proportion generally fell between 1901 and 1911. This was caused by the general decline in the proportion of female entrepreneurs after 1901, driven mainly by a drop in dressmaker business proprietors affected

\footnotetext{
11 The ten most common were carpenter, farmer, shoemaker, butcher, grocer, tailor, blacksmith, mason, wheelwright and house painter.
} 
by business concentration and mechanisation in the garment industry. However, the general stability of the other types, as well as the stability in overall proportions and gender balance seen in tables 10 and 11, the general continuity of the occupational breakdown, and the fairly even geographical distribution of these households shown in Figure 2, all suggest that the conditions supporting these co-entrepreneurial households were present throughout the period $1851-1911$.

A household might contain two or more entrepreneurs for several reasons. First, an entrepreneur already running a business might enter the household already containing another business proprietor, such as someone running a small-scale business lodging in the household of a relatively more substantial business proprietor as happened with Joseph Whelan, a 67year old hawker living as a lodger in Blackburn in 1891, he was lodging in the house of Francis O'Gorman, an optician (Whelan, 1891). Or two or more entrepreneurs might form a household, such as when two already existed entrepreneurs married; examples of this are hard to identify from the census given the ten year frequency, however, Adele and Henry Crabtree had been married less than a year when the 1911 census was taken and she was working on her own account as a French teacher, while he was an employer running a taxidermist business; although they may well have both been entrepreneurs before marrying and forming their two-person co-entrepreneurial household (Crabtree, 1911). Also, someone living in a household with another entrepreneur might start their own business, perhaps inspired by the other's example and guided by the expertise and other resources of the existing entrepreneur. At least some of the dressmaking daughters will have learnt their entrepreneurial skills and marketing from their mothers and fathers. In some cases, the second business may have been facilitated more explicitly by the first business, such as the food sellers building on an existing farming business to sell some of the produce, developing a form of portfolioenterprise. Or the second business may have been started by a family seeking to minimize 
risk or to allow someone who otherwise struggled to enter the waged labour market to contribute to the household income. The last case probably helps explain why so many of the co-entrepreneurs were female dressmakers, or laundresses. Dressmaking and laundry were sectors with low entry costs which could be carried on at home and thus were ideal for women who could not enter waged labour because they had to attend to domestic matters, or because they lived somewhere with few employment opportunities for women, such as South Wales or other mining areas (You, 2020). In all these cases the structural conditions, whether availability of waged labour, prevalence of lodgers and boarders, the necessity for all household members to contribute to the household income, or the need to guard against risk, changed relatively little during this period so the incidence and character of coentrepreneurship remained fairly stable.

\section{Conclusion}

This article has described some of the ways the household and family underpinned and interacted with business proprietorship in nineteenth- and twentieth-century England and Wales and how household resources enabled certain forms of business activity. However, the discussion has been restricted to the household involvement in entrepreneurial activities observable in the census, and it is clear that much is missing from this picture. Many household members will have worked in and helped run businesses owned or run by another household member, but their contribution has gone unrecorded in the census. For reasons discussed elsewhere this was particularly true for female household members (Higgs and Wilkinson, 2016). Other family firms were run by family members who did not live in the same household and thus cannot be identified from the census record. For these reasons we have not attempted to assess relative frequency of household business forms, though it is probable that co-resident family businesses were the most common. However, even with such 
limitations it has been possible to identify three of the most widespread forms of household entrepreneurship for the years 1851-1911, and to establish the characteristics of these businesses and assess if they changed over time.

The first, co-resident family businesses, saw family members working in the same occupation as an entrepreneurial relative. These were predominantly found in more marginal areas of the country and generally in small-scale businesses. As transport links improved, migration to urban centres continued and waged labour became more attractive, the frequency of these co-resident family businesses declined. Furthermore, the growth of compulsory schooling also affected the employment of children in family businesses. Additionally, it was no longer necessary for children to work in their parents' businesses in locations where other employment opportunities were slim; they could migrate away. Also, the increasingly integrated national market and the rise of branch stores meant that the marginal locations where co-resident family businesses had tended to be found no longer had as many independent enterprises; instead, goods and services formerly provided by a small family firm could be provided by a branch of a national chain, by buying through mail order and rail delivery, or by using improved transport to travel to a nearby population centre to purchase goods and services.

The second and third forms of household entrepreneurship, implicit partnerships and co-entrepreneurship, were more stable in their incidence, occupation and distribution across this period. This reflects the fact that the socio-economic conditions which made such forms of household economic activity attractive were more stable over the period. Partnership remained an attractive form of business organisation. Even as incorporation became more common it still allowed individuals to share risk, pool resources and to share the burden of running a business. Co-entrepreneurship was particularly useful in allowing household 
members, especially married women and co-resident children, to contribute to the household income and hedge the household against risk.

The discussion of these three forms of household entrepreneurship confirms the oftrepeated argument that the family and the household were vital to Victorian and Edwardian business and that this was a strong line of continuity with earlier period that was only starting to change slowly by the end of the period considered here (Davidoff, 2012; Barker, 2017). However, the individual-level data in I-CeM and the BBCE allows us, for the first time, to examine the precise forms this interaction took on a large scale, rather than relying on case studies. It shows that even though there was much change in business organisation in this period, notably the rise of incorporation, old forms of firm structure were still valued (Hannah, 1983). However, it also shows that these forms of organisation were contingent on the structural factors at play. Co-resident family businesses began to decline in some sectors as the economy became more integrated and as waged work became more attractive; partnerships and co-entrepreneurship, in contrast, remained useful because the conditions of insecurity and uncertainty which characterized entrepreneurship in this period, and to which these forms of organisation were remedies, remained relevant throughout the period.

Further work is required to examine how these kinds of entrepreneurship affected the overall performance of the English and Welsh economy in this period. However, it is important to note that the sheer variety of forms of household and family entrepreneurship visible in this period simply from the census data suggests that the relationship between entrepreneur, family, household and the economy is more complex than implied by those scholars who have laid the blame for Britain's relative decline at the door of the family firm (Chandler, 1990). Instead, as was the case for most entrepreneurs in England and Wales at this period, the business proprietors discussed above, and the households they resided in, were driven by the context they found themselves in. Co-resident family businesses arose 
because the family offered a ready supply of labour in locations where the labour market was tight; implicit partnerships provided a way to get many of the advantages of incorporation without the formality and expense of incorporating; and co-entrepreneurship allowed individuals who struggled to enter waged labour to develop a way to contribute to the household income. In these cases, and many others, the needs of the household shaped the structure of the business as much as the other way around.

\section{References}

Anderson, Michael (1984). The social position of spinsters in Mid-Victorian Britain. Journal of Family History, 9/4, 377-93

Anderson, Michael (1990). The social implications of demographic change. In F.M.L. Thompson (ed.), The Cambridge Social History of Britain, 1750-1950: Volume 2: People and their Environment (pp. 1-70). Cambridge University Press.

Barker, Hannah (2017). Family and Business During the Industrial Revolution. Oxford University Press.

Bennett, R.J. (2016). Interpreting business partnerships in late Victorian Britain. The Economic History Review, 69/4, 1199-1227.

Bennett, R.J., Montebruno, P., Smith, H. and van Lieshout, C. (2019b). Reconstructing entrepreneur and business numbers for censuses, 1851-81. Working Paper 9: 'Drivers of Entrepreneurship and Small Businesses', https://doi.org/10.17863/CAM.37738.

Bennett, R.J., Smith, H., van Lieshout, C., Montebruno, P. and Newton, G. (2019a), The Age of Entrepreneurship: Business Proprietors, Self-Employment and Corporations Since 1851. Routledge. 
Bennett, R.J., Smith, H., van Lieshout, C. and Newton, G. (2017). Business sectors, occupations and aggregations of census data, 1851-1911. Working Paper 5, 'Drivers of Entrepreneurship and Small Businesses', https://doi.org/10.17863/CAM.9874.

Burnette, Joyce (2008). Gender, Work and Wages in Industrial Revolution Britain. Cambridge University Press.

Capie, Forrest and Collins, Michael (1996). Industrial lending by English commercial banks, 1860s-1914: why did banks refuse loans? Business History, 38/1, 26-44.

Chandler, Alfred D. (1990). Scale and Scope. Harvard University Press.

Church, Roy (1993). The family firm in industrial capitalism: international perspectives on hypotheses and history. Business History, 35/4, 17-43.

Colli, Andrea (2003). A History of Family Business, 1850-2000. Cambridge University Press.

Colli, Andrea and Rose, Mary (2007). Family Business. In Geoffrey Jones and Jonathan Zeitlin (eds), The Oxford Handbook of Business History (pp. 194-217). Oxford University Press.

Cottrell, Philip (1980). Industrial Finance 1830-1914: The finance and organisation of English manufacturing industry. Croom Helm.

Crabtree, Adele (1891). The National Archives, RG14/31982/373, 1911 Census Household Schedule, Adele Crabtree.

Crossick, Geoffrey (2000). Meanings of property and the world of the petite bourgeoisie. In Jon Stobart and Alastair Owens (eds), Urban Fortunes: Property and Inheritance in the Town, 1700-1900 (pp. 50-78). Ashgate.

Davidoff, Leonore (2012). Thicker than Water: Siblings and their Relations, 1780-1920. Oxford University Press.

Davidoff, Leonore and Hall, Catherine (1997). Family fortunes: men and women of the English middle class, 1780-1850. Routledge. 
de Vries, Jan (2008) The Industrious Revolution: consumer behaviour and the household economy, 1650 to the Present. Cambridge University Press.

Dodman, Mary (1891). The National Archive, RG12/443/19/31, 1891 Census Enumerator's Book, Mary Dodman.

Ehmer, Josef (2001). Family and business among master artisans and entrepreneurs: The case of $19^{\text {th }}$-century Vienna. The History of the Family, 6/2, 187-202.

Erickson, Amy Louise (2008). Married women's occupations in eighteenth-century London. Continuity and Change, 23/2, 267-307.

Gamber, Wendy (1997). The Female Economy: The millinery and dressmaking trades, 18601930. Chicago University Press.

Garrett, Eilidh, Szreter, Simon, Schürer, Kevin and Reid, Alice (2001). Changing Family Size in England and Wales: place, class and demography, 1891-1911. Cambridge University Press.

Hannah, Leslie (1983). The Rise of the Corporate Economy. $2^{\text {nd }}$ edition. Methuen.

Hannah, Leslie (2014). Corporations in the US and Europe, 1760-1860. Business History, $56 / 6,865-99$.

Higgs, Edward (1983). Domestic servants and households in Victorian England. Social History, 8/2, 201-10

Higgs, Edward (2005). Making Sense of the Census Revisited: Census Records for England and Wales, 1801-1901. Institute of Historical Research and The National Archives.

Higgs, Edward and Wilkinson, Amanda (2016). Women, occupation and work in the Victorian censuses revisited. History Workshop Journal, 81/1, 17-38.

Hofmeester, Karin and Meerkerk, Elise van Nederveen (2017). Family, demography and labour relations. The History of the Family, 22/1, 3-13 
Jeffreys, James B. (1954). Retail Trading in Britain 1850-1950: A Study of Trends in Retailing with Special Reference to the Development of Co-operative, Multiple Shop and Department Store Methods of Trading. Cambridge University Press.

Laslett, Peter (1972). The History of the Family. In Peter Laslett (ed.), Household and Family in Past Time (pp. 1-90). Cambridge University Press.

Mackinney, Fred (1901). The National Archives, RG13/23/56/7, 1901 Census Enumerator's Book, Fred MacKinney.

Medick, Hans (1976). The proto-industrial family economy: the structural function of household and family during the transition from peasant society to industrial capitalism. Social History, 3, 291-315.

Nagata, Mary Louise (2017), The evolution of marriage, inheritance, and labor relations in the family firm in Kyoto. The History of the Family, 22/1, 14-33.

Nenadic, Stana (1993). The small family firm in Victorian Britain. Business History, 35/4, $86-114$

Nicholas, Tom (1999). Clogs to Clogs in Three Generations? Explaining entrepreneurial performance in Britain since 1850. Journal of Economic History, 59/3, 688-713.

Outram, Quentin (2017). The demand for residential domestic service in the London of 1901. Economic History Review, 70/3, 893-918.

Owens, Alastair (2001). Property. gender and the life course: inheritance and family welfare provision in early nineteenth-century England. Social History, 26/3, 297-315.

Owens, Alastair (2002). Inheritance and the life-cycle of family firms in the early industrial revolution. Business History, 44/1, 21-46.

Payne, Peter L. (1988). British Entrepreneurship in the Nineteenth Century. Macmillan. 
Pooley, Colin G. and Turnbull, Jean (1997). Leaving Home: the Experience of Migration From the Parental Home in Britain Since c. 1770. Journal of Family History, 22/4, $390-424$.

Rose, Mary B. (1993). Beyond Buddenbrooks: the family firm and the management of succession in nineteenth-century Britain. In Jonathan Brown and Mary B. Rose (eds), Entrepreneurship, Networks and Modern Business (pp. 127-43). Manchester University Press.

Sambridge, James (1901). The National Archives, RG13/1277/15/22, 1901 Census Enumerator's Book, James Sambridge.

Schürer, Kevin and Higgs, Edward (2014). Integrated Census Microdata (I-CeM), 18511911. [data collection]. Colchester, Essex: UK Data Archive [distributor], https://doi.org/10.5255/UKDA-SN-7481-1

Scranton, Philip (1993). Build a Firm, Start Another: The Bromleys and family firm entrepreneurship in the Philadelphia region. Business History, 35/4, 115-41.

Smith, Richard M. (1981). Fertility, economy, and household formation in England over three centuries. Population and Development Review, 7/4, 595-622.

van Lieshout, C., Smith, H., Montebruno, P. and Bennett, R.J. (2019). Female entrepreneurship: business, marriage and motherhood in England and Wales, 18511911. Social History, 44/4, 440-68.

Wall, Richard (1987). Leaving Home and the Process of Household Formation in Preindustrial England. Continuity and Change, 2/1, 77-101.

Whelan, Joseph (1891). The National Archives, RG12/3400/26/18, 1891 Census Enumerator's Book, Joseph Whelan. 
You, Xuesheng (2020). Women's labour force participation in nineteenth-century England and Wales: evidence from the 1881 census enumerators' books. Economic History Review, 73/1, 106-33. 


\begin{tabular}{cccc|ccc}
\hline & $\mathbf{1 8 5 1}$ & $\mathbf{1 8 6 1}$ & $\mathbf{1 8 8 1}$ & $\mathbf{1 8 9 1}$ & $\mathbf{1 9 0 1}$ & $\mathbf{1 9 1 1}$ \\
\hline Entrepreneurs & 5.3 & 4.6 & 5.1 & 5.0 & 4.8 & 4.6 \\
Workers & 4.7 & 4.6 & 4.8 & 4.7 & 4.6 & 4.5 \\
\hline
\end{tabular}

Table 1. Mean houseful size of entrepreneurs and workers, 1851-1911.

Source: BBCE and I-CeM. 


\begin{tabular}{lll}
\hline Household Type & Entrepreneur & Worker \\
\hline Solitary & 7.7 & 6.8 \\
No CFU & 5.9 & 3.1 \\
Simple & 67.3 & 75.6 \\
Extended & 16.8 & 12.7 \\
Multiple & 2.3 & 1.8 \\
Unclassified & 0.01 & 0.01 \\
\hline
\end{tabular}

Table 2. Household classification of entrepreneurs and workers, 1901. Source: BBCE and I-CeM. 


\begin{tabular}{|c|c|c|c|}
\hline Census & $\begin{array}{l}\text { Co-resident } \\
\text { businesses }\end{array}$ & Family & \% of all employers \\
\hline 1851 & 62,423 & & 31.1 \\
\hline 1861 & 44,593 & & 25.3 \\
\hline 1881 & 47,869 & & 26.0 \\
\hline$\overline{189 \overline{1}}$ & $\overline{79, \overline{3} \overline{7}}-$ & $-\pi$ & $-\overline{1} \overline{4} . \overline{7}------$ \\
\hline 1901 & 104,859 & & 18.9 \\
\hline 1911 & 103,619 & & 15.2 \\
\hline
\end{tabular}

Table 3. Co-resident family businesses, 1851-1911.

Source: BBCE and I-CeM. 


\begin{tabular}{lccc:ccc}
\hline Type & $\mathbf{1 8 5 1}$ & $\mathbf{1 8 6 1}$ & $\mathbf{1 8 8 1}$ & $\mathbf{1 8 9 1}$ & $\mathbf{1 9 0 1}$ & $\mathbf{1 9 1 1}$ \\
\hline Son(s) only & 10.2 & 10.1 & 9.3 & 4.1 & 8.4 & 7.5 \\
Daughter(s) only & 12.1 & 10.9 & 11.5 & 37.6 & 42.0 & 28.3 \\
Brother(s) only & 5.0 & 6.5 & 5.3 & 3.4 & 5.5 & 5.7 \\
Sister(s) only & 18.8 & 14.1 & 22.7 & 54.1 & 56.8 & 46.7 \\
Other family only & 5.5 & 8.3 & 7.0 & 9.9 & 19.6 & 19.8 \\
Mixed family & 10.1 & 13.6 & 12.3 & 6.9 & 17.6 & 12.7 \\
Family \& non-family & 5.7 & 5.8 & 7.0 & 9.2 & 16.1 & 16.6 \\
\hline
\end{tabular}

Table 4, Female co-resident employers by type of family business, 1851-1911.

Source: BBCE and I-CeM. 


\begin{tabular}{cccc}
\hline Year & Family & Non-Family & $\begin{array}{c}\text { \% of all } \\
\text { entrepreneur } \\
\end{array}$ \\
& & & households \\
\hline $\mathbf{1 8 5 1}$ & 9,025 & 3,326 & 3.5 \\
$\mathbf{1 8 6 1}$ & 6,684 & 1,677 & 2.6 \\
$\mathbf{1 8 8 1}$ & 7,871 & 1,966 & 2.8 \\
$\mathbf{1 9 0 1}$ & 48,362 & 9,037 & 4.3 \\
$\mathbf{1 9 1 1}$ & 59,461 & 9,869 & 4.6 \\
& 52,903 & 10,102 & 4.2
\end{tabular}

Table 5. Implicit household partnerships, 1851-1911.

Source: BBCE and I-CeM.

Note: in 1851-1881 households include at least one extracted entrepreneur but the partners may derive from non-response supplementation; for 1891-1911 the entire population of entrepreneurs is used. Non-family includes any household in which at least one non-family member is involved in the partnership. 


\begin{tabular}{lccc:ccc}
\hline Occupation category & $\mathbf{1 8 5 1}$ & $\mathbf{1 8 6 1}$ & $\mathbf{1 8 8 1}$ & $\mathbf{1 8 9 1}$ & $\mathbf{1 9 0 1}$ & $\mathbf{1 9 1 1}$ \\
\hline Farming & 31.0 & 30.0 & 24.6 & 13.8 & 11.4 & 14.1 \\
Mining & 0.4 & 0.6 & 0.4 & 0.3 & 0.4 & 0.8 \\
Construction & 11.0 & 12.0 & 9.0 & 3.5 & 3.8 & 4.7 \\
Manufacturing & 11.5 & 12.4 & 11.1 & 8.7 & 7.9 & 9.2 \\
Maker-dealer & 28.6 & 20.8 & 15.7 & 26.6 & 25.3 & 19.8 \\
Retail & 3.0 & 4.5 & 5.4 & 14.7 & 13.9 & 15.0 \\
Transport & 1.1 & 2.7 & 1.7 & 1.7 & 1.7 & 1.8 \\
Professional \& business services & 0.3 & 0.5 & 0.8 & 1.5 & 1.4 & 2.2 \\
Personal services & 1.3 & 1.8 & 13.8 & 13.5 & 13.8 & 11.5 \\
Agricultural produce processing \& dealing & 2.1 & 2.0 & 2.6 & 1.2 & 1.1 & 1.0 \\
Food sales & 8.0 & 10.7 & 12.0 & 10.1 & 12.7 & 12.3 \\
Refreshment & 1.1 & 1.6 & 2.0 & 3.2 & 5.6 & 6.4 \\
Finance \& commerce & 0.5 & 0.6 & 0.7 & 1.2 & 1.0 & 1.3 \\
\hline
\end{tabular}

Table 6. Implicit partnerships by sector (percentage), 1851-1911. Source: BBCE and I-CeM.

Note: For definition of sectors see (Bennett et al., 2017). 


\begin{tabular}{llll|lll}
\hline & $\mathbf{1 8 5 1}$ & $\mathbf{1 8 6 1}$ & $\mathbf{1 8 8 1}$ & $\mathbf{1 8 9 1}$ & $\mathbf{1 9 0 1}$ & $\mathbf{1 9 1 1}$ \\
\hline Female Only & 3.4 & 4.0 & 9.9 & 34.3 & 34.2 & 27.4 \\
Male Only & 64.8 & 57.7 & 58.0 & 38.1 & 37.7 & 43.2 \\
Female-Male & 31.9 & 38.3 & 32.2 & 27.7 & 28.1 & 29.4 \\
\hline
\end{tabular}

Table 7. Gender of implicit partners (percentage), 1851-1911.

Source: BBCE and I-CeM. 


\begin{tabular}{lcccc}
\hline & Family & Non-Family & Total & \% of \\
& & & & entrepreneurial \\
& & & households \\
& & & 5.1 \\
\hline 1851 & 12,652 & 5,220 & 17,872 & 4.9 \\
1861 & 10,305 & 5,710 & 16,015 & 4.5 \\
\hline 1881 & 11,911 & 3,989 & 15,900 & 5.1 \\
1901 & 54,288 & 13,918 & 68,206 & 5.2 \\
1911 & 57,031 & 14,828 & 77,944 & 4.8 \\
\hline
\end{tabular}

Table 8. Co-entrepreneurial households, 1851-1911.

Source: BBCE and I-CeM.

Note: households defined as in table 5. 


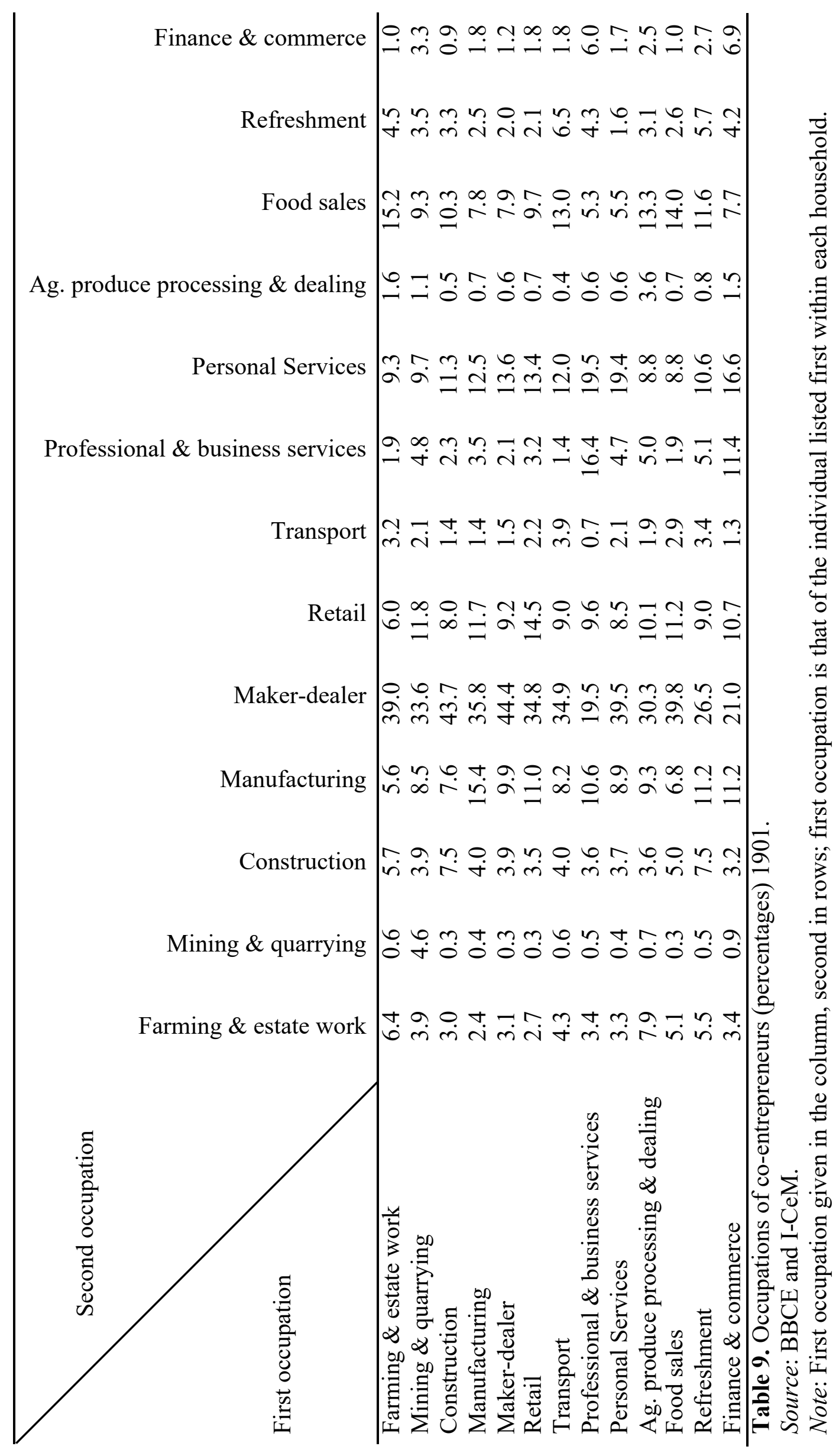




\begin{tabular}{lccc|ccc}
\hline & $\mathbf{1 8 5 1}$ & $\mathbf{1 8 6 1}$ & $\mathbf{1 8 8 1}$ & $\mathbf{1 8 9 1}$ & $\mathbf{1 9 0 1}$ & $\mathbf{1 9 1 1}$ \\
\hline Female & 30.8 & 27.2 & 34.6 & 41.0 & 40.0 & 35.5 \\
Male & 69.2 & 72.8 & 65.4 & 59.0 & 60.0 & 64.5 \\
\hline
\end{tabular}

Table 10. Gender of first-named co-entrepreneurs, 1851-1911.

Source: BBCE and I-CeM. 


\begin{tabular}{llll|lll}
\hline & $\mathbf{1 8 5 1}$ & $\mathbf{1 8 6 1}$ & $\mathbf{1 8 8 1}$ & $\mathbf{1 8 9 1}$ & $\mathbf{1 9 0 1}$ & $\mathbf{1 9 1 1}$ \\
\hline Father-son & 15.1 & 13.0 & 17.6 & 13.0 & 14.0 & 16.6 \\
Father-daughter & 13.5 & 9.1 & 13.9 & 17.7 & 17.4 & 14.1 \\
Mother-son & 3.7 & 2.6 & 3.4 & 4.0 & 4.1 & 3.6 \\
Mother-daughter & 1.8 & 1.5 & 3.0 & 5.5 & 5.2 & 3.3 \\
Husband-wife & 13.8 & 15.4 & 14.1 & 18.4 & 18.6 & 17.6 \\
Sister-Sister & 4.1 & 4.0 & 4.9 & 4.6 & 4.0 & 4.2 \\
Brother-Brother & 5.4 & 5.1 & 5.0 & 4.0 & 4.6 & 5.6 \\
Sister-Brother & 4.8 & 4.5 & 5.6 & 5.5 & 6.2 & 6.6 \\
Mixed \& other family & 9.6 & 10.0 & 7.8 & 7.4 & 7.1 & 7.4 \\
Family-boarder/lodger & 7.2 & 4.6 & 10.2 & 10.9 & 9.9 & 10.6 \\
Non-family only & 1.3 & 2.5 & 1.7 & 2.5 & 2.3 & 3.1 \\
Family-non-family & 19.5 & 27.7 & 12.8 & 6.6 & 6.6 & 7.3 \\
\hline Table 11. Co-entrepren & & & & & \\
\hline
\end{tabular}

Table 11. Co-entrepreneurial households by type of relationships between co-entrepreneurs (percentages for columns), 1851-1911.

Source: BBCE and I-CeM. 

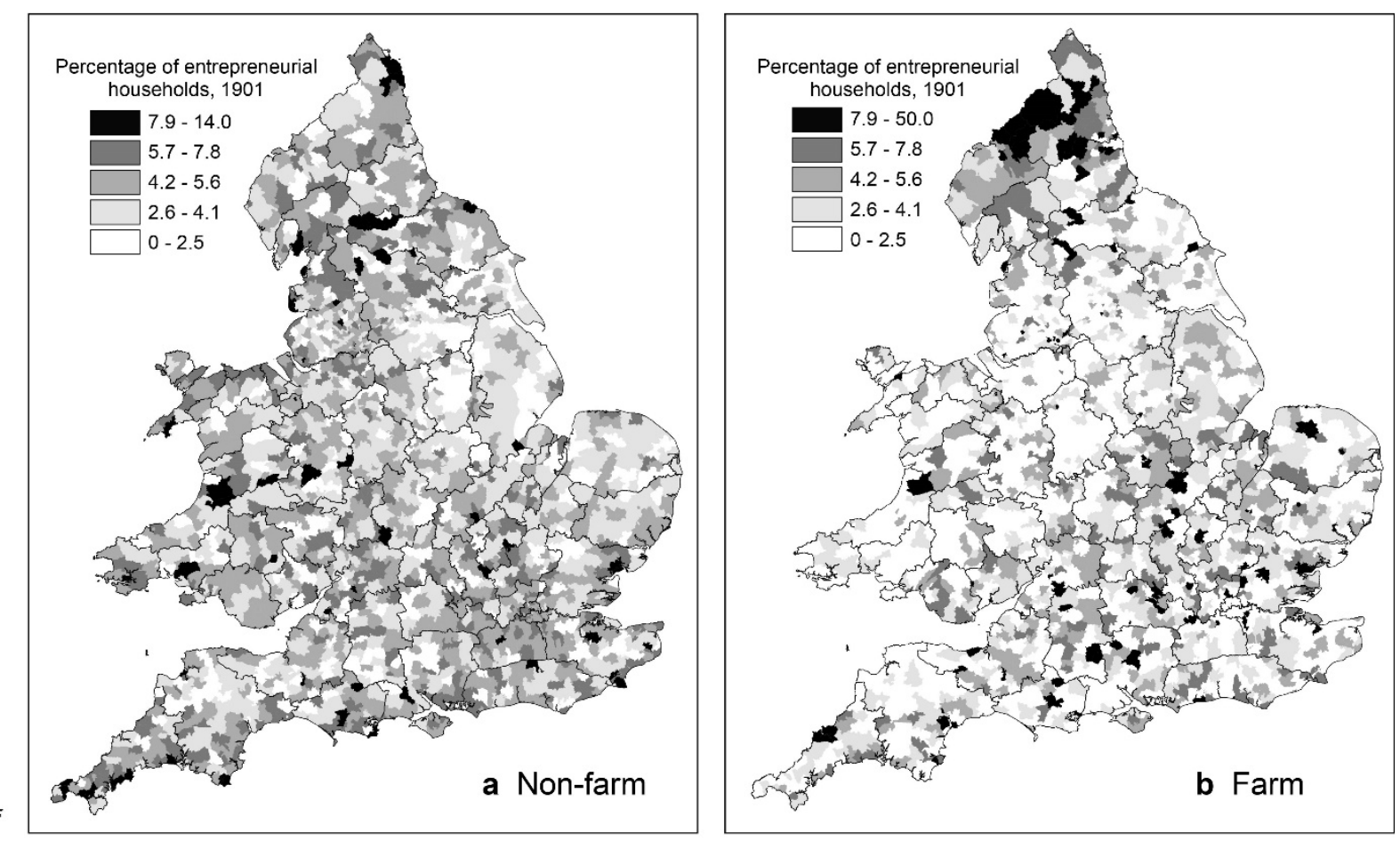

Figure 1. Partnerships as a percentage of all entrepreneurial households per RSD, nonfarmers and farmers 1901.

Source: BBCE and I-CeM. 


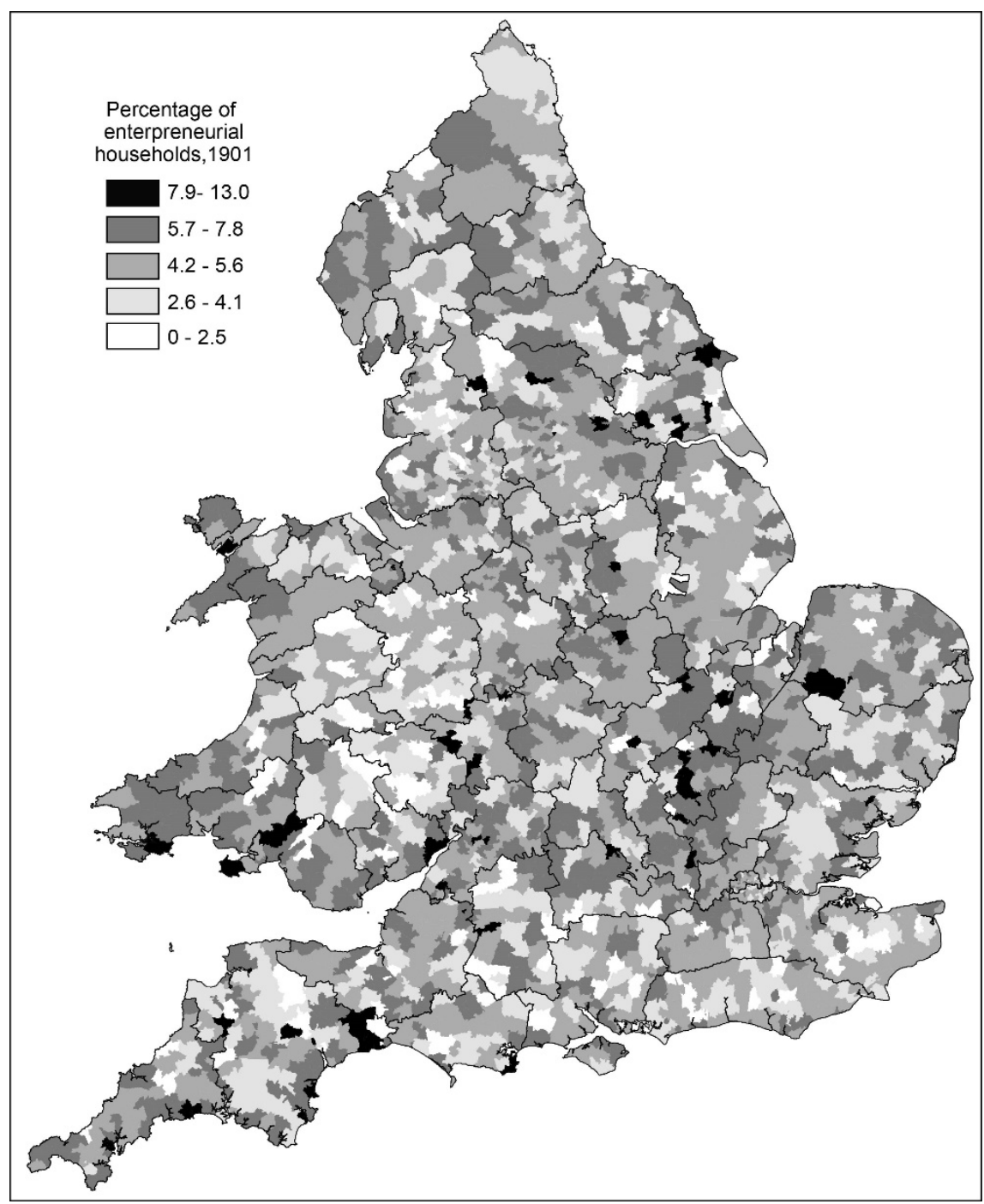

Figure 2. Co-entrepreneur households as a \% of all entrepreneurial households, 1901. Source: BBCE and I-CeM. 